\title{
Project Work Writing in BBS Fourth Years Course: Procedures and Practices
}

\author{
Prof. Puspa Raj Sharma, PhD
}

\begin{abstract}
This paper has been prepared with an objective to provide the guidelines to the BBS students to write the project work and teachers to guide their students in writing the project work and preparing the paper has included procedure of project work assignment prescribed by Office of the Dean, Faculty of Management, Tribhuvan University. The paper give some insight on necessary procedures of the submission of project work writing. It also give some practical insight to the faculty members who involved in the supervision.
\end{abstract}

Keywords: BBS, project work, report writing

\section{Need and Objective of Project Work}

The need of project work (PW) writing in Bachelor of Business Studies (BBS) level in Faculty of Management (FOM) is to develop the student's skill on doing independent research work in their specialization field and to enable them to present their work on a standard format of writing. The exercise that the students go through during the research and writing process becomes practical training for them that shall be highly beneficial to them in gaining practical knowledge. PW writing has been made compulsory in BBS program. The purpose of PW a great opportunity for students to develop marketable skills to prepare for the transition from academia into the workforce. The following are the some of the purpose of PW according to $\operatorname{FOM}(2013)$ dean office:

- Promote real-life learning of how organizations actually work.

- Provide students an opportunity to integrate their course work knowledge with application.

- Empower the teacher to relate to all the concepts with what is happening in business world.

- Develop inter-personal and communication skills.

- Provide opportunity to work closely with a faculty member.

- Develop data-processing and report writing skills (preliminary research training).

- Provide opportunity to make useful contacts.

\section{Objective of the Paper}

The objective of this paper is to highlight the procedures of PW writing in BBS level of FOM and the practices being adopted in the faculty. The paper also aims to raise some practical issues based on the experience of students, guide teachers, expert teachers and the administration; both campuses and dean office. 


\section{Review of Literature}

Woods (1999), some academics, however, stick to the idea of research as writing-up. For example, Woods says research writing is nothing like writing 'delightful' junior school essays or turning out 'cathartic bits of biography, diary or magazine articles'. Instead 'academic writing is a strongly disciplined activity, and we have to gear ourselves up for it.

Barnett (2005) argues that we need 'scholarly space' in order to pursue our research interests and 'intellectual and discursive space' in order to make our contributions to wider social debate rather than to be constrained by the distorting and performative restrictions of the Research Assessment Exercise (Barnett 2005).

Shrestha (2004) pointed out that writing is the important aspect in the syllabus of all the programs in FOM. In bachelor program, BBS, students have to write a field report in their third year on the elective course in sectoral area, in all the semester programs like Bachelor in Business Administration (BBA), Bachelor in Information Management (BIM), Bachelor in Hotel Management (BHM) and Bachelor in Travel and Tourism Management (BTTM), the students have to write PW or term paper. The business students at master level need more orientation and more depth in their writing process so that they feel comfortable in reading as well as independent writing during their graduation from FOM.

Shrestha further commented that after two years of the thesis/project work writing in MBS level, there are a number of experiences faced by the students, faculty (both supervisors and the external examiners) and the administration (Office of the Dean, campus/department and the Controller's Office). It will be useful to share these experiences regarding problems in Content of Thesis/PW. The format of thesis/ PW is not found to meet the standard criteria. Format covers the format of the cover page, the table of contents, the body of the work, the bibliography, and appendices.

The Bibliography, the references are not cited correctly. The main problems found are not to follow the standard method of bibliography. The size and authenticity of data- The size of data is sometimes insufficient and sometimes redundant. The source of data are not well cited and sometimes the data are irrelevant.

Badley (2009) expressed that academic writing, especially the writing of research articles, dissertations and theses, is often viewed in the literature as 'writing up'. It is as if first comes the research, an active creation of new knowledge, and then comes the writing, a relatively passive assembling of what has already been achieved. It is as if researching and writing were two entirely separate pocesses. Alternatively we may choose to conceive of academic writing as a set process which overlaps considerably with researching itself and, indeed, which may contribute dynamically to knowledge making.

Lamont's (2009) empirical work on academic evaluation in Humanities and Social Sciences disciplines. She found that the way in which individuals seek alignment between theory and method, theory and data, and in the clarity and appropriateness 
of articulation of theoretical position and contribution is, 'in part, a matter of taste and a response to varying disciplinary sensibilities’ (p. 183).

Devkota (2010), a review of literature needs to be written in two different places: in the proposal and in the dissertation itself. The general purpose of both these reviews is to provide the reader with an overview of the critical considerations already established vis-à-vis the text of subject matter under analysis. Although students writing the proposal will generally have read less in the area than those writing the dissertation, they are still expected to have read major critical in the chosen field of inquiry. The review of literature included in the proposal should be able to point at controversies or virgin fields where the research scholar may take sides or set out to explore the area. This review of literature is obviously going to be shorter than the one incorporated in the dissertation itself.

Sharma (2010) has evaluated fieldwork report since last one decade. Despite of a number of guidelines, many students were not clear in the skills of report writing. In this process author has found a number of mistakes done by the students in the process of writing fieldwork. The academic standard of students in writing the report is weak. Students are not sincere in conducting fieldwork study. They either copy from others or spend very little time in the organizations and write reports only to fulfill the formality. Most of the students are weaker in the presentation of facts, figures and overall administration of the fieldwork report. They commit common mistakes in writing bibliography and annex. In addition to this, they are found poor in the typography of the report (putting page, setting margin, and maintaining consistency). Majority of the students are not able to build linkage the data analysis with desired objectives, conclusion with findings, recommendations with conclusions Students should study and work hard on the reference of fieldwork and report writing. The work should not be taken as very lightly. The college should monitor to see whether students spend their two weeks in the concerned organization or not. It should coordinate the difficulties faced by the students and teachers. The college should provide adequate orientation and sufficient inputs as per the need of the students and teachers. The refreshment seminar on research methodology should be conducted time to time.

Business Barry O’Mahony, Elena Verezub, John Dalrymple and Santina Bertone (2013 Vol. 6 No1 pp. 22-34,.) claimed in Journal of International Education that achieving quality standards in postgraduate education, particularly among Higher Degree by Research (HDR) students, can be challenging. In addition to the diverse educational and cultural backgrounds of these students, thesis writing frequently involves the development of new skills associated with the comprehension of a large volume of information, critical analysis and the development of an academic writing style. Many students need support in one or all of these key areas. Universities currently provide a number of different writing support activities to address students' needs. This research found that both students and their supervisors expressed satisfaction with the service offered. Also it was found that the writing quality of submitted theses is improving; the costs of thesis editing have reduced; HDR students appear to be more satisfied with and confident of their academic writing; the attractiveness of the $\mathrm{PhD}$ program has been enhanced, as judged by the increase in $\mathrm{PhD}$ enquiries and the quality of potential applicants

Svein and Thune (2016) report on a study of the quality assessment of dissertations/thesis, and asks whether examiner characteristics influence assessment of research quality in thesis/ 
dissertations. Utilizing a multi-dimensional concept of quality of dissertations, they look at differences in assessment of research quality, and particularly test whether prior relationship to supervisor, examiners' assessment experience and the regional affiliation of examiners influence assessment, also controlling for academic fields and type of higher education institutions. The results indicate that the regional affiliation and previous experience of committee members influence quality assessment significantly, but that the relationship to supervisor(s) was of little importance

\section{Procedures of Project Work Writing}

\section{Proposal of the project work}

The PW writing is compulsory in BBS level of FOM in the respective specialization courses. BBS under the supervision of a faculty member of the campus. The education of future manager will be incomplete without exposure to organizational reality. Therefore, the final $\mathrm{PW}$ is made an essential academic requirement for the fourth year students in all concentration courses. The following questions may generally be raised about proposed PW. Pay attention to these questions while planning PW and writing the proposal. As a PW researcher one should be able to evaluate these questions satisfactorily.

- Is your proposed title in acceptable format? Does it reflect accurately your contents?

- Is there consistency between the problem, objectives and research methods?

- Have you reviewed the latest research work on your research area?

- Is the design that you propose to adopt to conduct your research exploratory, descriptive, or case study appropriate?

- Why did you select this design?

- How will you select your samples?

- How will you collect data?

- What instruments will you use?

- Why did you select this method of data collection?

- How will you analyze the data? Please explain the procedures of data preparation and presentation.

- What will be the action/practical implications of your PW?

- Are your citations and references in line with APA format?

\section{Duration}

To write a PW, students will undergo a field work and spend four weeks studying and learning from the organization during the time fixed by the campus/college. After the field work, the student will write a project report on the format prescribed by the FOM and submit it to the college/campus for evaluation.

\section{Format of the Report}

The PW report should be categorized into three main parts. They are preliminary materials, body of the report and supplementary sections You are required to assemble the thesis report in the following order: 


\section{Preliminary Materials}

- Title Page of the Thesis

- Approval Sheet

- Certification of Authorship

- Acknowledgments

- Table of Contents

- List of Tables and Figures

- Abstract

\section{Body of the Report}

- Chapter I: Introduction

- Chapter II: Literature Review

- Chapter III: Methodology

- Chapter IV: Results

- Chapter V: Conclusions

\section{Supplementary Materials}

- References

- Appendices

\section{Submission in the Respective Campus and Evaluation of the PW}

The student may also be asked to present the report to the general class and/ or faculty members. The evaluation of the report will be made by a team of external and internal examiners appointed by the by the Research department of the respective campus/college. The PW should relate to the student's specialization. The student must complete the prescribed number of hours of practical work in all courses requiring such work to the satisfaction of the concerned department. The final practical examination will be conducted jointly by team of external and internal examiners appointed by the Office of Controller of Examinations. A student will have to pass the theoretical, practical and PW examinations separately in all the courses having theoretical, PW and/or practical components.

\section{Some Suggestions to the Faculty Member in the Process of Supervision}

In the process of supervision faculty members are involved in different steps. Therefore it would be useful and effective to follow guidelines accordingly.

\section{Initial Meetings}

- Try to find out what the student wants to do for his/her research. Is the topic relevant? Within the capability of the student? Will the data be accessible?

- Develop rapport with the student based on mutual respect and open communication.

- After the initial meetings, discuss with the student about the expectations and requirements.

- Meet the student regularly whether or not he/she has any finished work to show to you. 


\section{Define study plan/milestones}

- Set and agree on the requirements and standards expected of the PW and the program of study.

- Ensure completion of each milestone within a reasonable timeline.

\section{Monitor study progress}

- Set regular meeting schedules.

- Ensure on-time submission of chapters or write-ups.

- Show positive attitudes. Always encourage students.

\section{Provide resources}

- Involve students in improving their learning ability.

- Guide from where to get the materials.

- Be accessible to the student.

\section{Advise on research and publications}

- Give appropriate independence and freedom to students

- Tell the student about academic integrity and ethics.

- Encourage and guide on how to develop academic writing skills.

\section{Conclusion}

The Four years BBS program under FOM has aim to produce students equipped with conceptual knowledge of business management and with developed skill of research capability in business environment in national and global perspective. To achieve the aim FOM focuses student's study on theoretical aspects as well as practical exposures in research. The procedures of BBS research and the practices being adopted so far has been experienced to be highly useful to the students as well as teachers. The external evaluation of the PW outside the respective campuses has created an atmosphere where the teachers get an opportunity to compare the quality standard among various campuses, which has also been considered positive impact on the interaction among the teachers involved in research activities. The FOM recognizes the need for both breadth and depth in the total academic pattern. Therefore, the curriculum for BBS degree comprises four separate and distinct course components:. A strong foundation allied areas of business such as language, economic analysis, legal environment and quantitative method to prepare graduates to understand, analyze and comprehend the management concepts, theories and practices. Core business studies encompassing and integrating all functional areas to provide graduates with and appreciation of the diversity and inter-relationship of business and management issues. The opportunity to concentrate in one area of specialization such as accounting, finance, human resources management and marketing in order to provide graduates with some degree of functional expertise. In addition to this the requirement of $\mathrm{PW}$ add value to the students, however there are certaint challenges to implement the PW. Lack of dedication of the large numbers BBS students, poor motivation of the administrative support, low motivation of the faculty members in the research work and others are the challenges to implement it. 


\section{BIBLIOGRAPHY}

Business, B. O., Elena, V., John, D. \& Santina, B. (2013). Project work writing Journal of International Education, 6, 22-34.

Demeulemeester, J. L., \& Denis, R. (1995). A causality analysis of the link between higher education and economic delopment. Economics of Education Review, 14(4), 251-261.

Katuwal, S. B. (2011). Global Financial crisis and higher education in Nepal. International Journal of Business Management, Economics and Information Technology, 3, 39-45.

Katuwal, S. B. (2011 a). Socio-economic inequality: An implication for managing labour market. International Journal of Business Policy and Economics, 4, 51 - 64.

Koirala, P. (2005).Vision and mission of management education in Nepal. Tribhuvan University Journal, XXV, 27-32.

Lamont, M. (2009). How professors think: Inside the curious world of academic judgment. Cambridge, MA: Harvard University Press

Badley, G. (2004). Reading an academic journal is like doing ethnography. Forum: Qualitative Social Research 5, http://www.qualitative-resea rch.net/index.php.fqs/article/ view/660/1428 (accessed February 15, 2009).

Badley, G. (2007). Don't stop the carnival _ three cheers for the RCE. Environment and Planning A 39, no. 2: 239 41.

Barnett, R. ( ed. 2005). Reshaping the university: New relationships between research, scholarship and teaching. Maidenhead, UK: SRHE \& Open University Press.

Bourdieu, P., \& Wacquant, L. J. D. (1992). Invitation to reflexive sociology. Cambridge, MA: Polity.

Thune, T., S. Kyvik, S. Sörlin, T. B. Olsen, A. Vabø, \& C. Tømte. (2012). PhD education in a knowledge society: An evaluation of PhD education in Norway. Oslo: NIFU.

Hames, I. (2007). Peer review and manuscript management in scientific journals: Guidelines for good practice. Blackwell Publishers in association with ALPSP.

Shrestha, S. (2004). Thesis writing: Procedure and practices. The Journal of Nepalese Business Studies, 69-74.

Sharma, P. R. (2004). Micro-finance programs and its sustainability in Nepal. Paper presented in a Seminar organised by SAP-Nepal, Pokhara, July 5

Sharma, P. R. (2004). Micro-finance: A powerful tool for social transformation, its challenges and principles. The Journal of Nepalese Business Studies, 69-74.

Sharma, P. R. (2010). Field work and report writing. Mamata 5, 69-74.

Sharma, P. R. (2011). Impact of microfinance on women empowerment. Pokhara: TOLI.

Sharma, P. R. (2011). Sustainability fo microfinance institution: An opinion survey. Pokhara: TOLI.

Svein, K., \& Taran, T. (2016 ). Assessing the quality of PhD dissertations: A survey of external committee members assessment and evaluation in higher education. http://dx.doi. org/10.1080/02602938.2014.956283

Note: The source of reference is the materials provided by the Office of the Dean, Faculty of Management, T.U website and Research Workshop organized by the Research Committee, PN Campus. The supporting reference is the informal discussion and feedback received from the students, teachers, and the office, and my own experience in administration of the Thesis/ PW evaluation in the Dean's Office. 